\title{
Conservation conversations: a typology of barriers to conservation success
}

\author{
Michele Jeanette Sanders, Laura Miller \\ Shonil A. Bhagwat and Alex Rogers
}

\begin{abstract}
Despite considerable achievements in the field of conservation, biodiversity continues to decline and conservation initiatives face numerous barriers. Although many of these barriers are well known, for example insufficient funding and capacity, there has been no systematic attempt to catalogue and categorize them into a typology. Because risks compromise the conservation mission, any barrier to success is a risk. Here we present the first attempt at identifying key barriers. We analyse extensive interviews with 74 conservationists, primarily from Africa but with international experience, to identify potential risks to their projects and use that information to create a typology of barriers to conservation success. We draw on the literature to explain the prevalence of some of the barriers identified. We suggest that this typology could form the basis of heuristic tools that conservationists can use to identify and manage potential risks to their projects, thereby improving decisionmaking, strategic planning and, ultimately, overall impact. The typology is also useful for the conservation community (comprising conservationists and funders) to help implement better practices and improve the likelihood of success. We present examples of such work already underway and suggest more can be done to continue to improve.
\end{abstract}

Keywords Barriers to success, conservation, failure, risk management, typology

Supplementary material for this article is available at https://doi.org/10.1017/So030605319000012

\section{Introduction}

There has been a notable increase in the scope and 1 scale of conservation activities. On average the sector receives USD 1.1 billion annually in aid from government

Michele Jeanette Sanders* (Corresponding author) and Alex Rogers $\dagger$ Zoology Department, University of Oxford, Oxford, OX1 3PS, UK

E-mail msandersoxon@gmail.com

LAURA Miller $\$$ Synchronicity Earth, London, UK

Shonil A. Bhagwat The Open University, Milton Keynes, UK

${ }^{*}$ Also at: Synchronicity Earth, London, UK

†Current address: REV Ocean, Somerville College, University of Oxford, Oxford, UK

‡Currently: Independent consultant

Received 29 July 2018. Revision requested 14 September 2018.

Accepted 9 January 2019. First published online 12 December 2019. and multilateral agencies (Miller et al., 2012), and possibly even more from private sources, with philanthropy overtaking traditional sources of aid (Nelson, 2009).

With this support, conservationists, defined here as any individual, group or organization undertaking conservation actions, have been able to reduce the risk of extinction for many species (e.g. Hoffman et al., 2015), yet biodiversity loss continues globally (Butchart et al., 2010). The world's wildlife populations have fallen by $60 \%$ since 1970 (WWF, 2018). There is an urgent need to increase the success of conservation, and some practices from the corporate sector could prove useful.

The success of for-profit companies in the corporate sector is typically measured through productivity, profit or return on assets (Wall et al., 2004). Success in conservation, however, is more difficult to define. There has been much debate over the definition and measurement of conservation success (e.g. Margoluis et al., 2013), perhaps because success is both subjective and pluralistic. Definitions vary in different contexts and for different stakeholders (Meredith et al., 2018). Here we define success as the agreement by all relevant stakeholders that outcomes have had positive benefits on species, habitats and/or ecosystems, that barriers have been successfully overcome or managed, and that the intervention or action was good value for money.

In the corporate sector, success is underpinned by, amongst other things, the management of risk (Merna \& Al-Thani, 2008), something that is still not well understood and implemented in non-profit organizations (Herman, 2010). Contrary to the popular view that risks relate mainly to adverse events such as accidents, risk management is actually about helping an organization to advance its mission.

Fundamentally, risk management involves identifying key barriers to success in a timely manner (Cadbury, 1992). These might include problems within an organization (e.g. inappropriate organizational structure, poor staff recruitment and training, inadequate cash flow) or outside it (e.g. changing government policy, turbulent economic environment, poor public perception). Once barriers are identified, the risk management process assesses their likelihood and potential impact, and identifies the resources that could prevent or mitigate the risks (Cadbury, 1992). Effective risk management therefore enables organizations, both for- and non-profit, to identify and monitor significant barriers and take timely action. This makes them more effective in forward planning and strategy development, and more likely to achieve organizational aims (Charity Commission, 
2010) by increasing confidence in achieving their desired outcomes, effectively constraining barriers and threats to acceptable levels and, critically, taking informed decisions about exploiting opportunities (Grant, 2012).

Because overcoming barriers to success through effective risk management frees up resources for mission-related activities (Herman, 2010), conservationists would benefit from understanding and mitigating risks that compromise the success of their missions. There are tools available to help. The UK Charity Commission's (2010) guide to risk management and various capacity assessment tools (e.g. BirdLife International, 2008) mostly focus on internal risks, such as inappropriate governance structures or weak leadership. Various studies have also examined conservation successes or failures and tried to identify causes (e.g. see Manolis et al., 2009; Black et al., 2011; Bottrill et al., 2011). However, such tools do not guide users through the process of risk assessment, nor do they ensure that all types of risks are considered.

Typologies can potentially help to categorize the range of risks that organizations face, facilitating better risk management. The field of climate change adaptation, for example, has used typologies presented by Adger et al. (2007), Burch (2010), Biesbroek et al. (2013) and Burch et al. (2014) to find more strategic ways to address climate change adaptation. To date, there has been no similar attempt to categorize barriers to conservation success. A typology of such barriers would thus be useful to inform risk management for conservationists. Here we aim to develop such a typology. Our main aims are to: (1) identify internal and external barriers to conservation success at local and international levels, and categorize these barriers into a heuristic typology; (2) examine geographical differences in the categories of barriers reported by conservationists; (3) discuss how the typology of barriers to conservation success could provide a starting point in organizational risk management; and (4) review the examples of work already being done by some forwardthinking members of the conservation and non-profit communities to ameliorate barriers to success.

\section{Methods}

We followed an inductive approach (Bryman, 2016) to ensure that conservationists' views are accurately reflected without being influenced by the researchers. Although there is an abundance of academic and grey literature discussing challenges to conservation, our goal was to gain insights directly from conservationists.

We conducted semi-structured interviews with 27 conservationists in South Africa and 32 in Kenya during October 2012-December 2014. We selected these countries because their rich wildlife is coming under increasing pressure despite the large number of local and international conservationists working to protect it. As conservation hubs, these countries also have large numbers of conservationists in relatively close proximity, which limited researchers' travel time between interviews.

We sent out requests for interviews by e-mail, with subsequent follow up by e-mail or telephone. All interviews were informal and in-depth, most lasting 1-2 hours. The conversational tone of interviews, with open-ended questions, was intended to encourage more detailed answers. Interviewees were assured their anonymity would be protected and that only consolidated findings would be published.

We identified and selected all interviewees through professional networks and based on knowledge and experience. Most held director or senior management positions. Initial contact was made with 71 individuals from 60 organizations. Additional interviewees were identified through snowball sampling (Valentine, 2005). Where availability was limited and interviews were delegated to less experienced individuals within the organization, we requested that interviewees had at least 3 years of direct conservation experience. In some larger organizations, we interviewed more than one person. If the individuals within one organization worked together closely, they were interviewed together, but if they were involved in different projects or in different areas of work, they were interviewed separately.

Our purposive sample included representatives from governmental and non-governmental organizations, and academic institutions. However, the vast majority were from non-governmental organizations. Although we aimed for our sample to be representative of the conservation community, we found it particularly difficult to interview people in smaller, grassroots organizations and government organizations. Our sample is therefore not completely representative of all actors within conservation.

Because many interviewees represented iconic organizations in Africa, other areas or organizational types were underrepresented. We therefore interviewed a further 15 conservationists from outside South Africa and Kenya, including from the UK, Philippines, Democratic Republic of the Congo and Australia. The small number of people in this group is not representative of the wider conservation community, but it provided additional insight and ensured that we captured a wider range of conservation contexts. Furthermore, although the majority of our interviewees were based in Africa, not all had always been there. Their views and opinions therefore extend beyond the African context. Overall, we interviewed 74 people from 64 organizations.

All interviewees were asked two questions: 'What barriers or challenges prevent conservation organizations from achieving their goals?' If time permitted, they were also asked: 'If money was no constraint, what would be the solution?' We chose to use the words 'barriers' and 
'challenges' rather than 'risks' because of the commonly held view that risks only apply to specific events, such as accidents or power cuts (Charity Commission, 2010; Herman, 2010). We asked additional probing questions to gain a deeper understanding where required, and to ensure responses were clearly understood. Participants were given time to discuss any issue for as long as they wished. We made no attempt to lead participants in any particular direction during the conversation. All interviews were conducted by MJS, thus ensuring consistency in approach and analysis (Bryman, 2016).

Interviews were transcribed using shorthand typing, with permission for doing so obtained from each interviewee. We coded transcripts to identify key themes into which responses could be categorized. The informal nature of the discussions meant that barriers and solutions were often discussed interchangeably. When specifically asked about solutions, many interviewees continued to discuss barriers or merely suggested the opposite of the barriers as solutions. Our analysis therefore focused on issues, whether framed as problems (there are not enough skilled people) or solutions (we need to train more people). We revisited all interview transcripts following coding to ensure consistent logic was applied throughout. Where necessary, we made further contact with interviewees to seek clarification.

In designing the typology we used an iterative, inductive approach to categorize responses. We consulted a range of literature to provide additional explanation in the presentation of our results.

\section{Results}

All interviewees were candid and forthcoming, discussing a wide range of topics. Rather than utilizing barrier typologies used in other areas such as climate change, which were inappropriate in our context, we used obvious high level criteria, split where necessary to capture different subthemes.

At the top layer, issues were grouped by origin. Internal issues are those completely within an individual organization's control. Operational issues arise outside an organization, but are within the control of the conservation community, which comprises both conservationists and their funders. It is important to distinguish between these two categories, because it reveals how many practices can hinder, rather than improve, conservation success. External issues are completely outside the conservation community's control. Within each of these categories, we identified a number of different themes:

Internal issues within an organization's control Leadership is about driving the organization's achievement of its vision, whereas management is concerned with achieving efficiency and stability during that process. Governance primarily revolves around oversight and organizational direction, and finance is concerned with acquiring, managing and spending funds.

Operational issues within the control of the conservation community but outside that of an individual organization Themes within this group included the manner in which funding is awarded, involvement of and ownership by local communities, continuous improvement, collaboration between different stakeholders within the sector, and coordination of effort.

External issues outside an organization's control Themes within this category included behaviour, both of people and practitioners locally and the global population more widely, issues specific to the local context, and wider global issues.

The full list of issues discussed under each category and theme, and the number of interviewees that discussed each category, is shown in Table 1. Details providing a more nuanced picture of interviewees' statements about these issues are given in Supplementary Table 1.

\section{Discussion}

We firstly introduce the top five issues identified by interviewees from each of South Africa and Kenya, and by the total interviewee sample (the latter including conservationists from outside these two countries; Table 2). We explore why these barriers may be foremost in people's minds and suggest possible reasons for differences in prevalence between South Africa and Kenya: of the overall top five issues, only two ('local capacity' and 'impact/monitoring and evaluation') were amongst the top five in both South Africa and Kenya, whereas the other three ('strategy', 'community buy-in' and 'availability of funding') were amongst the top five in only one of these two countries. We have not included the sample of conservationists from other countries in this analysis as a distinct group, as it is not representative of the rest of the world.

\section{Local capacity (external issue)}

One issue raised by $81 \%$ of interviewees was the challenge of finding and keeping skilled and experienced staff. Interviewees reported many young people are drawn to the higher income and more attractive benefits offered by the private sector, leaving a relatively small pool of suitably skilled and passionate people available to fill positions requiring a high level of skills but offering a relatively low income. One interviewee said conservationists are expected to understand complex ecological processes and complicated socio-economic and political interactions. They have to write grant applications and progress reports, manage staff and control financial budgets. Many interviewees said finding people with training and experience in these diverse 
TABLE 1 A typology of barriers to effective conservation. Each of the three categories is further divided into themes, which in turn comprise several issues. A quote capturing the essence of the interviewees' statements is given for each theme. The percentage of interviewees from each group discussing each theme is shown. The top five issues for each group are marked with *. Note that there was a tie for fifth place for South Africa, so there are six top issues in that column.

\begin{tabular}{|c|c|c|c|c|c|c|}
\hline Ther & nes \& issues & Quotes & $\begin{array}{l}\text { South } \\
\text { Africa (\%) } \\
n=27\end{array}$ & $\begin{array}{l}\text { Kenya } \\
(\%) \\
n=32\end{array}$ & $\begin{array}{l}\text { Other } \\
(\%) \\
n=15\end{array}$ & $\begin{array}{l}\text { Total } \\
(\%) \\
\mathrm{n}=74\end{array}$ \\
\hline \multicolumn{7}{|c|}{ External, further divided into behaviour (B), local context (LC) \& wider issues (W) } \\
\hline $\mathrm{B}$ & Cultural/ethical norms & 'Local culture needs to be taken into account' & 26 & 66 & 33 & 43 \\
\hline B & Changing behaviour & 'Doom and gloom messaging for conservation isn't working' & 19 & 34 & 20 & 26 \\
\hline LC & Local capacity/infrastructure & $\begin{array}{l}\text { 'It's really hard to find good people' 'Logistics are difficult when things on the ground change, } \\
\text { like roads being washed away or fuel prices increasing' }\end{array}$ & $93^{*}$ & $84^{\star}$ & $53^{*}$ & $81^{*}$ \\
\hline LC & Political will/mainstreaming & 'We're struggling to make the case for conservation with government' & 33 & 50 & 20 & 38 \\
\hline LC & $\begin{array}{l}\text { Enforcement of laws/ } \\
\text { regulations }\end{array}$ & 'People are not implementing regulations properly' & 30 & 50 & 7 & 34 \\
\hline LC & Local context & 'You need to understand the actual context, not just what it looks like on paper' & 26 & 38 & 27 & 31 \\
\hline LC & Government institutions & $\begin{array}{l}\text { 'Working with government is hard because they work at their own pace' 'It's a bureaucratic } \\
\text { nightmare to get permits and access to data' }\end{array}$ & 22 & 41 & 27 & 31 \\
\hline LC & Corruption & 'Poor pay creates an environment where corruption can occur' & 22 & 38 & 0 & 24 \\
\hline LC & Local community structure & 'Working only with one community and not taking the views of others into account is a problem' & 11 & 38 & 13 & 23 \\
\hline LC & Human-wildlife interactions & 'Poaching makes animals angry, which increases human-wildlife conflict' & 15 & 22 & 7 & 16 \\
\hline LC & Land tenure & $\begin{array}{l}\text { 'Out of anger, local communities with no land tenure have shunned conservation. Because the } \\
\text { land isn't theirs, there's no point participating because they won't benefit' }\end{array}$ & 0 & 25 & 0 & 11 \\
\hline LC & Security/conflict/war & 'Conflict or war means anyone not local pulls out' & 0 & 16 & 13 & 9 \\
\hline $\mathrm{W}$ & $\begin{array}{l}\text { Increased demand for } \\
\text { land/resources }\end{array}$ & 'People are pushed into forests and water-stressed areas as more land is needed for agriculture' & 44 & 59 & 7 & 43 \\
\hline W & $\begin{array}{l}\text { People disconnected } \\
\text { from nature }\end{array}$ & 'City folk don't really know about nature or conservation' & 30 & 44 & 27 & 35 \\
\hline W & $\begin{array}{l}\text { Complexity of external } \\
\text { factors }\end{array}$ & $\begin{array}{l}\text { 'The number of threats is increasing very rapidly. You deal with one threat here and another } \\
\text { rises quickly' }\end{array}$ & 30 & 34 & 13 & 28 \\
\hline \multicolumn{7}{|c|}{ Operational, comprising continuous improvement $(\mathrm{CI})$, coordination $(\mathrm{C})$, funding $(\mathrm{FU})$, local involvement \& impact (LII) \& reputation (R) } \\
\hline CI & Learning/knowledge sharing & 'We are notoriously bad at learning from our interventions' & 48 & 63 & 40 & 53 \\
\hline CI & Discussing failure & 'Discussing failure can affect future funding' & 22 & 25 & 13 & 22 \\
\hline $\mathrm{C}$ & Integrated approach & $\begin{array}{l}\text { 'The scale of impacts is bigger than the size of the interventions, so we're not working at the } \\
\text { right scales' }\end{array}$ & 52 & $72^{*}$ & 47 & 59 \\
\hline $\mathrm{C}$ & Collaboration & 'Collaborations are often very superficial' & 52 & 41 & 20 & 41 \\
\hline $\mathrm{C}$ & Coordination of effort & 'Politics prevents us from adopting a coordinated approach' & 15 & $69^{*}$ & 27 & 41 \\
\hline $\mathrm{C}$ & $\begin{array}{l}\text { Unintended consequences } \\
\text { of conservation }\end{array}$ & 'Benefits from conservation attract more people to the area' & 11 & 3 & 7 & 7 \\
\hline FU & Availability of funding & 'People care about people, so the amount of money going into conservation is small' & $67^{*}$ & 66 & 47 & $62^{*}$ \\
\hline $\mathrm{FU}$ & Long-term support & $\begin{array}{l}\text { 'There is a disconnect between meaningful outputs and getting money out in line with } 3-5 \text { year } \\
\text { funding policy' }\end{array}$ & $70^{*}$ & 56 & 40 & 58 \\
\hline FU & Funding allocation & 'Overhead is more expensive than many donors think' & 41 & 50 & 33 & 43 \\
\hline FU & Donor-led conservation agenda & 'Everyone changes their tune based on what donors are funding' & 44 & 38 & 27 & 38 \\
\hline
\end{tabular}


Table 1 (Cont.)

\begin{tabular}{|c|c|c|c|c|c|c|}
\hline \multicolumn{2}{|c|}{ Themes \& issues } & \multirow{2}{*}{$\begin{array}{l}\text { Quotes } \\
\text { 'Interventions are unsustainable when funding runs out' }\end{array}$} & \multirow{2}{*}{$\begin{array}{l}\text { South } \\
\text { Africa (\%) } \\
\mathrm{n}=27 \\
22\end{array}$} & \multirow{2}{*}{$\begin{array}{l}\text { Kenya } \\
(\%) \\
\mathrm{n}=32 \\
47\end{array}$} & \multirow{2}{*}{$\begin{array}{l}\text { Other } \\
(\%) \\
\mathrm{n}=15 \\
20\end{array}$} & \multirow{2}{*}{$\begin{array}{l}\begin{array}{l}\text { Total } \\
(\%)\end{array} \\
\mathrm{n}=74 \\
32\end{array}$} \\
\hline$\overline{\mathrm{FU}}$ & $\begin{array}{l}\text { Unsustainable conservation } \\
\text { actions }\end{array}$ & & & & & \\
\hline FU & Competition & 'There are many organizations clamouring to do very similar things' & 37 & 28 & 13 & 28 \\
\hline FU & $\begin{array}{l}\text { Donor selection of } \\
\text { conservationists }\end{array}$ & 'Some organizations are good at raising money but not implementing' & 30 & 41 & 0 & 28 \\
\hline FU & Donor due diligence & 'Filled in forms mask weaknesses because NGOs want the money' & 22 & 41 & 13 & 28 \\
\hline FU & Desire for recognition & 'Everyone wants to make their own mark, so we're too focused on novelty' & 26 & 34 & 20 & 28 \\
\hline FU & $\begin{array}{l}\text { Relations between funders \& } \\
\text { conservationists }\end{array}$ & 'There is a lack of open communication between donor and organization when problems arise' & 22 & 28 & 13 & 23 \\
\hline FU & Dishonesty in the sector & 'Conservation agencies lie to funders about what they've done or are doing' & 11 & 13 & 44 & 26 \\
\hline FU & $\begin{array}{l}\text { Application \& reporting } \\
\text { processes }\end{array}$ & $\begin{array}{l}\text { 'Donors have created bureaucratic procedures, but won't pay for the staff needed to prepare } \\
\text { them' }\end{array}$ & 22 & 19 & 7 & 18 \\
\hline LII & Community buy-in & 'The process of developing trust with locals takes time' & 56 & $75^{\star}$ & $60^{*}$ & $65^{\star}$ \\
\hline LII & $\begin{array}{l}\text { Local ownership/ } \\
\text { empowerment }\end{array}$ & $\begin{array}{l}\text { 'NGOs should be aiming to make themselves redundant in an area, not make the area reliant } \\
\text { on them' }\end{array}$ & 30 & 63 & $53^{*}$ & 49 \\
\hline LII & $\begin{array}{l}\text { Conservation-development } \\
\text { interplay }\end{array}$ & $\begin{array}{l}\text { 'We have a challenge of making conservation an economic choice, which is hard in a poor } \\
\text { society' }\end{array}$ & 37 & 56 & 27 & 43 \\
\hline LII & Community consultation & 'Proper consultation and participation of people helps identify risks' & 11 & 22 & 13 & 16 \\
\hline $\mathrm{R}$ & Accountability & $\begin{array}{l}\text { 'There's no follow-up to check what you've paid for has been done, and that it's actually achieving } \\
\text { anything' }\end{array}$ & 22 & 19 & 7 & 18 \\
\hline $\mathrm{R}$ & Reputation of conservation & 'We have to stop being so radical and ecocentric. We have to remember that there is a human need' & 22 & 19 & 0 & 16 \\
\hline \multicolumn{7}{|c|}{ Internal, further divided into finances $(F)$, governance $(G)$, leadership $(\mathrm{L})$ \& management $(\mathrm{M})$} \\
\hline F & Financial management & 'Project managers don't understand the need for financial management so don't keep receipts' & 33 & 13 & 20 & 22 \\
\hline G & Governance & 'The directors often don't have the time that is needed to fully address issues' & 30 & 6 & 13 & 16 \\
\hline $\mathrm{L}$ & Impact & 'Sometimes it can be hard to show what you're doing, but you are making progress' & $70^{*}$ & $72^{*}$ & $60^{*}$ & $69^{*}$ \\
\hline $\mathrm{L}$ & Strategy & $\begin{array}{l}\text { 'The average manager is always doing things. They don't have time to look at the reports that } \\
\text { come out from the research guys to see if it can solve their problems' }\end{array}$ & $89^{*}$ & 47 & $73^{*}$ & $68^{*}$ \\
\hline $\mathrm{L}$ & Leadership & $\begin{array}{l}\text { 'Ego is an issue in conservation. The needs of the organization need to be bigger than the } \\
\text { individual running it' }\end{array}$ & $67^{\star}$ & 44 & 27 & 49 \\
\hline M & General management & 'There is more interest in doing the interesting work than the bureaucratic processes' & 63 & 13 & 33 & 35 \\
\hline M & People management & $\begin{array}{l}\text { 'People out in the field have no strong home connection or strong ability to network socially } \\
\text { or promote themselves, so they miss out' }\end{array}$ & 41 & 16 & 13 & 24 \\
\hline
\end{tabular}


TABLE 2 The top five issues raised by interviewees from South Africa and Kenya, and by the total interviewee population (which included 15 conservationists from other countries). The percentage of interviewees discussing each issue is given in parentheses. Note that there was a tie for fifth place for South Africa, so six issues are included for that country.

\begin{tabular}{lll}
\hline South Africa $(\mathrm{n}=27)$ & Kenya $(\mathrm{n}=32)$ & Total $(\mathrm{n}=74)$ \\
\hline Local capacity $(93)$ & Local capacity $(84)$ & Local capacity (81) \\
Strategy (89) & Community buy-in (75) & Impact/monitoring \& evaluation (69) \\
Impact/monitoring \& evaluation (70) & Impact/monitoring \& evaluation (72) & Strategy (68) \\
Long-term support (70) & Integrated approach (72) & Community buy-in (65) \\
Leadership (67) & Co-ordination of effort (69) & Availability of funding (62) \\
Availability of funding (67) & & \\
\hline
\end{tabular}

skills was difficult. This could be a result of limited training available to small organizations, particularly in developing countries. Many interviewees reported having little time or money to invest in training or development, possibly because of time and resource constraints.

South African interviewees in particular mentioned problems with staff retention and recruitment: 93\% raised this issue. South Africa has a long history of conservation, a large number of state-run national parks, and the greatest number of conservationists in Africa, more than twice as many as Kenya (Brockington \& Scholfield, 2010b). Competition amongst conservation organizations for highly skilled and passionate individuals is therefore greater in South Africa, a problem possibly exacerbated by local education deficiencies (Chisholm, 2004; Fleish, 2008) and legal requirements for active promotion of previously disadvantaged groups over those who may be more skilled and/or experienced (Krüger, 2011).

\section{Strategy (internal issue)}

Many interviewees described conservation efforts as lacking strategy, often operating in crisis mode. The need for strategy is also clearly articulated in the literature (e.g. Jepson \& Canney, 2003). Strategic planning enables non-profit organizations to develop short- and long-term goals, and ensure that limited resources are appropriately allocated (McHatton et al., 2011). If clear, a strategy can ensure that objectives and methods are well thought through and articulated, providing coherence and focus in pursuit of the mission (Kaplan, 2001). Interviewees were frustrated by the lack of resources available to develop strategies, especially given the urgency of new and emerging threats to biodiversity. They recognized a need to examine assumptions underpinning their approaches, but had little time to do so. Although there may be clarity over what organizations want to achieve, it was less obvious how they could go about it given the resource constraints they faced.

\section{Community buy-in (operational issue)}

Nearly two-thirds of interviewees identified the need for, and challenges of, securing support from local communities that have often lived in an area for generations. One pointed out that the concept of conservation can be alien to these people. Another said poverty can prevent conservation from being a viable choice for local communities. Community expectations are often unmanaged. Some interviewees gave examples of broken promises and communities losing out as benefits from interventions meant to support the community are captured by other people or groups. Others spoke of evictions and displacement in the name of conservation. Community buy-in was more frequently discussed in Kenya, featuring in the country's top five issues. Active evictions of communities from their homes in Kenya at the time of our interviews (Survival International, 2015) could have contributed to this.

\section{Impact/monitoring and evaluation (internal issue)}

Monitoring and evaluation are central to adaptive management, providing an opportunity to reflect on which interventions are working and which need to be revised (Salafsky \& Margoluis, 2003). They are therefore essential to project management and development (Stem et al., 2005). Although interviewees agreed that monitoring and evaluation were important, they stated they did not have the right tools to effectively assess conservation initiatives. This is because progress is not fast or linear and therefore impacts can be difficult to measure. Furthermore, reasons for success may not be obvious, making it difficult to define and report on them. The academic literature also describes the challenges in assessing conservation impacts (e.g. Kapos et al., 2009), and confirms there is no satisfactory method for measuring impact consistently or attributing benefits to specific interventions (e.g. BOND, 2006).

\section{Long-term support (operational issue)}

Many South African and Kenyan interviewees discussed longterm funding. South African interviewees also emphasized the mismatch between short-term funding and long-term conservation goals. There is agreement in the literature that short-term funding is problematic in conservation 
(e.g. Jepson \& Canney, 2003; Sayer \& Wells, 2004; Tempesta \& Otero, 2013) because it does not give enough time to produce, promote and implement successful programmes (Keppel et al., 2012), and does not support locally-driven conservation efforts (Nelson, 2009), instead advancing global conservation agendas (Rodríguez et al., 2007). These impacts may be more acute in South Africa, which has twice as many conservation organizations as Kenya (Brockington \& Scholfield, 2010b), but attracts a similar amount of conservation funding (Brockington \& Scholfield, 2010a).

\section{Leadership (internal issue)}

Local capacity issues could explain why leadership issues ranked highly amongst South African interviewees. Leadership, defined as 'the ability to influence, inspire and motivate people, organizations and institutions to achieve, and in many cases go beyond, their goals' is a key contributor to institutional performance, stability and adaptability (United Nations Development Programme, 2010, p. 20). Its translation into, and importance in, conservation is increasing (e.g. Manolis et al., 2009; Black et al., 2011; Gutiérrez et al., 2011). A number of South African interviewees said it was impossible to find effective leaders, whereas others gave examples of individual egos being put above the cause. Their concerns are borne out in the literature. For example, one study of high-impact non-profit organizations found that the best leaders put their organizations and causes above themselves, sharing leadership and empowering others to take action (Grant \& Crutchfield, 2008).

\section{Availability of funding (operational issue)}

Most non-profit organizations are completely reliant on external sources of funding (Hull \& Lio, 2006). Limited funding was raised as a challenge by $62 \%$ of interviewees, and is well described in the literature (e.g. Sachedina, 2011), where biodiversity conservation is portrayed as a low priority for donors. Although private philanthropy has increased significantly (Hammack, 2006), environmental causes attract $<5 \%$ of it in the UK and USA (Sherlock \& Gravelle, 2009; Murray et al., 2014). Funding for conservation is well below the estimated total funding needed by conservation organizations (e.g. McCarthy et al., 2012). With tens of thousands of active environmental organizations (Scholfield \& Brockington, 2008), competition for funding is intense.

Integrated approach and co-ordination of effort (operational issues)

Two issues that show geographical differences are integrated approaches to conservation, and coordination of effort. Both featured in the top five issues in Kenya but not in South
Africa. The number of non-profit organizations operating across Africa has grown considerably (Brockington \& Scholfield, 2010b). Although South Africa's conservation community is bigger, interviews revealed a more inclusive approach to conservation. Interviewees often knew each other personally, and some spoke of forums allowing them to communicate and collaborate. Conversely, in Kenya interviewees often described a competitive, piecemeal approach to conservation. Interviewees expressed frustration at the lack of coordination and information sharing and criticized organizations duplicating one another's work and obtaining funding but doing little active conservation.

Some interviewees reported international donors awarded funding to the best grant-writers, not the best conservationists. The literature confirms persistence of this problem throughout the charitable sector (e.g. Unwin, 2004). Some interviewees said better coordination between conservationists and their funders, and a more integrated approach that considered whole landscapes rather than individual species or habitats, would result in better outcomes. Several respondents provided examples of where this is already happening, offering their opinion on how this eliminates some of the problems identified above, but many said there was still a long way to go in achieving more widespread cohesion in the sector.

\section{Interconnectedness of barriers}

A clear message emerging from our interviews was that there is no easy way to assess what affects conservation success or effectiveness. Instead, every conservationist faces multiple barriers. Some are specific to or more pronounced in particular locations, whereas others apply more generally within the conservation sector as a whole. In addition, barriers are often interconnected, resulting in cumulative impacts on conservationists and their ability to deliver results. For example, funding can be more difficult to secure (operational issue), particularly for small organizations, when more organizations join the conservation sector or if international donors change their focus. A lack of funding can in turn make it more difficult for organizations to manage their cashflow (internal issue), attract or retain high-quality employees (external issue) or show resilience when natural disasters or conflicts arise locally (external issue). With some organizations not delivering on their stated aims, funders may implement more onerous application and reporting processes (operational issues), which in turn can reduce capacity within the organization to deliver results, reassess strategic goals and reflect on its performance (internal issues).

\section{The way forward}

Our research highlights the plethora of barriers to success that conservationists face, and we suggest that this 
information can be used to increase the likelihood of success or to operate more effectively. This can be achieved by each conservation organization using the typology to identify and manage its own risks and barriers to success, and by the conservation sector reflecting on how its processes and procedures could be changed to improve performance. We consider each of these approaches in turn.

Effective organizational risk management involves identifying risks specific to an organization and responding to them in an appropriate way (Merna \& Al-Thani, 2008). Our typology presents all risks identified by our interview sample and shows that not every risk is applicable to every organization. Instead, each organization and intervention carries its own unique set of risks. Our typology provides a starting point for conservationists to consider which barriers may prevent them from achieving their goals. This could help to move conservationists towards a more systematic approach, proposed by Black et al. (2013), in which knowledge of natural systems and human behaviour, and the variations therein, inform decision-making and problem solving. To do this, conservationists need to identify barriers both inside and outside their organizations, and then determine whether the organization has the internal tools and/or capacity to respond appropriately. If not, the organization can identify how it could acquire such tools and/or build capacity, or even reconsider whether its proposed strategy can be effective given the presence of the identified barriers.

To determine risks to their success and effectiveness, conservation organizations could use our typology to identify potential barriers, and then carry out a SWOT (Strengths, Weaknesses, Opportunities, Threats) analysis, a tool commonly employed by private sector companies. Such analysis can help conservation organizations to identify their unique strengths and weaknesses, and reflect on how these might help to seize opportunities and avoid threats present in the operating environment (Helms \& Nixon, 2008). Once barriers to success have been identified, organizations can devise strategies to manage them, increasing their chances of achieving their goals.

Effective risk management is not a one-off exercise because the barriers faced by conservationists change over time (Merna \& Al-Thani, 2008). New threats and challenges emerge as the local context or the internal structure of an organization changes. Risk management should therefore become part of standard operating procedures and be carried out on an ongoing basis. An embedded approach to risk would ensure that conservationists and their funders have the tools needed to properly face, address and overcome barriers to conservation success. Risk management can significantly improve internal performance in nonprofit organizations (Golini et al., 2015) and risk reduction has been shown to add value to shareholder wealth in forprofit companies (Godfrey et al., 2009). We therefore suggest it can add value to the work conservationists undertake.
Our typology suggests that there are many external challenges over which the conservation sector has limited influence (e.g. population growth, political will). There is, however, significant scope for the sector to remove or minimize the operational barriers that are within its control. We found many initiatives already underway to address some of these operational barriers. We highlight a few of those as exemplars of what is possible.

Non-profit donors are starting to realize the burden they place on non-profit organizations, particularly small ones, and work is being done to address this. Large numbers of funders are reconsidering the future of funding and identifying how the burden they create could be alleviated (e.g. through less paperwork, shared due diligence processes or better collaboration; Bearman, 2013; Longhurst, 2016). For conservation specifically, a forum of African conservationists and their funders was held in 2017 to consider how to strengthen and support effective conservation models and organizations (Maliasili Initiatives, 2017). Although all this work is in its infancy, it is encouraging that funders are trying to increase the impact of their funding.

There is a growing acknowledgement that working in collaboration can achieve better results, and individual studies are providing evidence of this in conservation (e.g. Liu et al., 2014; Kark et al., 2015). As a result, more collaborations are being set up in the conservation sector, both amongst conservationists and amongst their funders. For example, the Cambridge Conservation Initiative (2012) is a collaboration between the University of Cambridge and conservation organizations operating in and around Cambridge. Members work together under a shared strategy and set of operating procedures to create solutions for society and strengthen conservation leadership and capacity globally. Oceans5 (2019) is a collaboration of international funders that combine their knowledge, experience and funding to support large, opportunistic projects and campaigns to establish marine reserves and constrain overfishing. Their joint funding provides more than any single funder can usually deliver.

It is encouraging to see that there is already work being done, both within the conservation community and by the wider donor base, to address some of the barriers identified in this study. However, there will need to be better sharing of knowledge about the drivers of successes and failures of conservation initiatives. Better management of internal and external risks by conservation organizations, combined with more helpful practices employed by the donor community, would improve the effectiveness and success of conservationists, and hopefully slow the loss of biodiversity globally.

Acknowledgements We thank Synchronicity Earth, the University of Oxford's Department of Zoology and Merton College for funding MJS, and all interviewees for their participation. 
Author contributions Project design: MJS, LM, with input from AR; interviews: MJS; data analysis: MJS, with input from LM, AR, SB; writing: MJS; revision: all authors.

\section{Conflicts of interest None.}

Ethical standards This research abided by the Oryx guidelines on ethical standards. All e-mail communications and procedures received the appropriate research ethics approvals from the University of Oxford.

\section{References}

Adger, W.N., Agrawala, S., Mirza, M.M.Q., Conde, C., O'Brien, K., Pulhin, J. et al. (2007) Assessment of adaptation practices, options, constraints and capacity. In Climate Change 2007: Impacts, Adaptation and Vulnerability. Contribution of Working Group II to the Fourth Assessment Report of the Intergovernmental Panel on Climate Change (eds M.L. Parry, O.F. Canziani, J.P. Palutikof, P.J. van der Linden \& C.E. Hanson), pp. 717-743. Cambridge University Press, Cambridge, UK.

Bearman, J. (2013) Project Streamline: Practices that Matter. Grants Manager's Network, Washington, DC, USA.

Biesbroek, G.G., Termeer, C.J.A.M., Klostermann, J.E.M. \& KaвAт, P. (2013) On the nature of barriers to climate change adaptation. Regional Environmental Change, 13, 1119-1129.

Birdife International (2008) Capacity Assessment Tool for Site Support Groups. BirdLife International, Nairobi, Kenya.

Black, S.A., Groombridge, J.J. \& Jones, C.G. (2011) Leadership and conservation effectiveness: finding a better way to lead. Conservation Letters, 4, 329-339.

Black, S.A., Groombridge, J.J. \& Jones, C.G. (2013) Using better management thinking to improve conservation effectiveness. ISRN Biodiversity, 2013, 784701.

BOND (2006) A BOND Approach to Quality in Non-Governmental Organisations: Putting Beneficiaries First. A report by Keystone and AccountAbility for the British Overseas NGOs for Development (BOND). Keystone and AccountAbility, London, UK.

Bottrill, M.C., Hockings, M. \& Possingham, H.P. (2011) In pursuit of knowledge: addressing barriers to effective conservation evaluation. Ecology and Society, 16, 14.

Brockington, D. \& Scholfield, K. (2010a) Expenditure by conservation nongovernmental organizations in sub-Saharan Africa. Conservation Letters, 3, 106-113.

Brockington, D. \& Scholfield, K. (2010b) The conservationist mode of production and conservation NGOs in sub-Saharan Africa. Antipode, 42, 551-575.

Bryman, A. (2016) Social Research Methods. 5th edition. Oxford University Press, Oxford, UK.

BURCH, S. (2010) In pursuit of resilient, low carbon communities: an examination of barriers to action in three Canadian cities. Energy Policy, 38, 7575-7585.

Burch, S., Berry, P. \& Sanders, M. (2014) Embedding climate change adaptation in biodiversity conservation: a case study of England. Environmental Science \& Policy, 37, 79-90.

Butchart, S.H.M., Walpole, M., Collen, B., van Strien, A., Scharlemann, J.P.W., Almond, R.E.A., Baillie, J.E.M. et al. (2010) Global biodiversity: indicators of recent declines. Science, $328,1164-1168$.
CAdBury, A. (1992) Report of the Committee on the Financial Aspects of Corporate Governance. Gee, London, UK.

Cambridge Conservation Initiative (2012) The CCI Strategy 2012-2020. CCI, Cambridge, UK. Http://www.cambridgeconservation. org/cci-strategy-2012-2020 [accessed 8 July 2019].

Charity Commission (2010) Charities and Risk Management: a Guide for Trustees. Http://www.charity-commission.gov.uk/ Publications/cc26.aspx [accessed 8 July 2019].

Chisholm, L. (2004) Changing Class: Education and Social Change in Post-Apartheid South Africa. HSRC Press, Cape Town, South Africa.

Fleish, B. (2008) Primary Education in Crisis: Why South African Schoolchildren Underachieve in Reading and Mathematics. Juta and Company Ltd, Cape Town, South Africa.

Godfrey, P.C., Merrill, C.B. \& Hansen, J.M. (2009) The relationship between corporate social responsibility and shareholder value: an empirical test of the risk management hypothesis. Strategic Management Journal, 30, 425-445.

Golini, R., Kalchschmidt, M. \& Landoni, P. (2015) Adoption of project management practices: the impact on international development projects of non-governmental organizations. International Journal of Project Management, 33, 650-663.

Grant, P. (2012) The Business of Giving: the Theory and Practice of Philanthropy, Grantmaking and Social Investment. Cass Business Press, London, UK.

Grant, H.M. \& Crutchfield, L. (2008) The hub of leadership: lessons from the social sector. Leader to Leader, Spring 2008, $45-32$.

Gutiérrez, N.L., Hilborn, R. \& Defeo, O. (2011) Leadership, social capital and incentives promote successful fisheries. Nature, 470, 386-389.

Hammack, D.C. (2006) American debates on the legitimacy of foundations. In The Legitimacy of Philanthropic Foundations: United States and European Perspective (eds K. Prewitt, M. Dogan, S. Heydemann \& S. Toepler), pp. 49-98. Russell Sage Foundation, New York, USA.

Helms, M.M. \& Nixon, J. (2008) Exploring SWOT analysis - where are we now? A review of academic research from the last decade. Journal of Strategy and Management, 3, 215-251.

Herman, M.L. (2010) Risk management. In The Jossey-Bass Handbook of Non-Profit Leadership and Management. 3 rd edition (eds D.O. Renz \& Associates), pp. 642-666. Jossey-Bass: a Wiley Imprint, San Francisco, USA.

Hoffmann, M., Duckworth, J.W., Holmes, K., Mallon, D.P., Rodrigues, A.S.L. \& STUART, S.N. (2015) The difference conservation makes to extinction risk of the world's ungulates. Conservation Biology, 29, 1303-1313.

Hull, C.E. \& Lio, B.H. (2006) Innovation in non-profit and for-profit organizations: visionary, strategic, and financial considerations. Journal of Change Management, 6, 53-65.

Jepson, P. \& Canney, S. (2003) The State of Wild Asian Elephant Conservation in 2003. A Report to Elephant Family. Conservation Direct, Oxford, UK.

KAPLAN, R.S. (2001) Strategic performance measurement and management in nonprofit organizations. Nonprofit Management \& Leadership, 11, 353-370.

Kapos, V., Balmford, A., Aveling, R., Bubb, P., Carey, P., Entwistle, A. et al. (2009) Outcomes, not implementation, predict conservation success. Oryx, 43, 336-342.

Kark, S., Tulloch, A., Gordon, A., Mazor, T., Bunnefeld, N. \& Levin, N. (2015) Cross-boundary collaboration: key to the conservation puzzle. Current Opinion in Environmental Sustainability, 12, 12-24. 
Keppel, G., Morrison, C., Watling, D., Tuiwawa, M.V. \& Rounds, I.A. (2012) Conservation in tropical Pacific island countries: why most current approaches are failing. Conservation Letters, 5, 256-265.

KRUGGER, L.P. (2011) The impact of black economic empowerment (BEE) on South African businesses: focusing on ten dimensions of business performance. South African Business Review, 15, 207-233.

Liu, S.C., Gillespie, N., Atchison, N. \& Andrew, P. (2014) The recovery programme for the regent honeyeater Anthochaera phrygia: an example of conservation collaboration in Australia. International Zoo Yearbook, 48, 83-91.

Longhurst, R. (2016) The Future of Funding: How Can We Foster the Leadership, Action and Conditions Required to Enable Civil Society in the Global South to Thrive? British Overseas NGOs for Development (BOND), London, UK.

Maliasili Initiatives (2017) From Crisis to Solutions: Changing the Conversation on African Conservation. A Forum on African Conservation Impact. Maliasili Initiatives, Underhill, USA.

Manolis, J.C., Chan, K.M., Finkelstein, M.E., Stephens, S., Nelson, C.R., Grant, J.B., \& Dombeck, M.P. (2009) Leadership: a new frontier in conservation science. Conservation Biology, $23,879-886$.

Margoluis, R., Stem, C., Swaminathan, V., Brown, M., Johnson, A., PlacCI, G. et al. (2013) Results chains: a tool for conservation action design, management, and evaluation. Ecology and Society, 18, 22-31.

McCarthy, D.P., Donald, P.F., Scharlemann, J.P.W., Buchanan, G.M., BALmFord, A., Green, J.M.H. et al. (2012) Financial costs of meeting global biodiversity conservation targets: current spending and unmet needs. Science, 338, 946-949.

Mchatton, P.A., Bradshaw, W., Gallagher, P.A. \& Reeves, R. (2011) Results from a strategic planning process benefits for a nonprofit organization. Nonprofit Management and Leadership, $22,233-249$.

Meredith, H.M.R., St. John, F.A.V., Collen, B., Black, S.A. \& Griffiths, R.A. (2018) Practitioner and scientist perceptions of successful amphibian conservation. Conservation Biology, $32,366-375$.

Merna, T. \& Al-Thani, F. (2008) Corporate Risk Management. and edition. John Wiley \& Sons, Chichester, UK.

Miller, D.C., Agrawal, A. \& Roberts, J.T. (2012) Biodiversity, governance, and the allocation of international aid for conservation Conservation Letters, 6, 12-20.

Murray, P., Cracknell, J., Godwin, H. \& Scholfield, K. (2014) Where the Green Grants Went 6. Environmental Funders Network, London, UK.

Nelson, F. (2009) Conservation and aid: designing more effective investments in natural resource governance reform. Conservation Biology, 23, 1102-1108.
OCEANS5 (2019) Https://oceans5.org [accessed September 2019].

Rodríguez, J.P., Taber, A.B., Daszak, P., Sukumar, R., Valladares-Padua, C., Padua, S., Aguirre, L.F. et al. (2007) Globalization of conservation: a view from the south. Science, $317,755-756$

SACHEDINA, H.T. (2011) Disconnected nature: the scaling up of African Wildlife Foundation and its impacts on biodiversity conservation and local livelihoods. In Capitalism and Conservation (eds D. Brockington \& R. Duffy), pp. 135-155. Wiley-Blackwell, Chichester, UK.

SAlafsky, N. \& Margoluis, R. (2003) What conservation can learn from other fields about monitoring and evaluation. BioScience, $53,120-122$

SAYER, J.A. \& Wells, M.P. (2004) The pathology of projects. In Getting Biodiversity Projects to Work (eds T.O. McShane \& M.P. Wells), pp. 35-48. Columbia University Press, New York, USA. Scholfield, K. \& Brockington, D. (2008) Non-Governmental Organisations and African Wildlife Conservation: a Preliminary Analysis. BWPI (Brooks World Poverty Institute) Working Paper 8o. Http://hummedia.manchester.ac.uk/institutes/gdi/publications/ workingpapers/bwpi/bwpi-wp-80o9.pdf [accessed 4 September 2019].

Sherlock, M.F. \& Gravelle, J.G. (2009) An Overview of the Nonprofit and Charitable Sector. CRS Report for Congress. Congressional Research Service, Washington, DC, USA.

Survival International (2015) 'Kenyan Government Forcing Us into Extinction': Evictions of Sengwer Tribe Escalate. Http://www. survivalinternational.org/news/9932 [accessed 4 September 2019].

Stem, C., Margoluis, R., Salafsky, N. \& Brown, M. (2005) Monitoring and evaluation in conservation: a review of trends and approaches. Conservation Biology, 19, 295-309.

Tempesta, M. \& Otero, M. (2013) Guide for Quick Evaluation of Management in Mediterranean MPAs. WWF Italy, Rome, Italy and IUCN Center for Mediterranean Cooperation, Málaga, Spain.

United Nations Development Programme (2010) Capacity Development: Measuring Capacity. United Nations Development Programme, New York, USA.

Unwin, J. (2004) The Grant Making Tango: Issues for Funders. The Baring Foundation, London, UK.

Valentine, G. (2005) Tell me about. ..: using interviews as a research methodology. In Methods in Human Geography: a Guide for Students Doing a Research Project (eds R. Flowerdew \& D. Martin), pp. 110-127. Routledge, Abingdon, UK.

Wall, T.D., Michie, J., Petterson, M., Wood, S.J., Sheehan, M., Clegg, C.W. \& West, M. (2004) On the validity of subjective measures of company performance. Personnel Psychology, 57, 95-118.

WWF (2018) Living Planet Report 2018: Aiming Higher. WWF International, Gland, Switzerland. 